Вчені записки ТНУ імені В. І. Вернадського. Серія: Філологія. Соціальні комунікаџіï. 2019. Т. 30 (69). № 1, Ч. 2. С. 154-159.

2. Асєєв Г.Г. Управління сучасним документообігом: теорія, структура, методи / Г.Г. Вісник Книжкової палати. Київ, 2004. № 4. C. 17-19.

DOI https://doi.org/10.30525/978-9934-26-005-6-8

\title{
STRATEGIC COMMUNICATIONS INTERDEPARTMENTAL COOPERATION IN EDUCATION AND SCIENCE AMONG LEADING EDUCATIONAL ESTABLISHMENTS OF UKRAINE
}

\author{
Kushnir V. O. \\ Candidate of Sciences in Public Administration, \\ Doctoral Student at the Educational and Research Centre \\ for Strategic Communications in the sphere \\ of National Security and Defence \\ The National Defence University of Ukraine \\ named after Ivan Cherniakhovskyi
}

\section{Izhutova I. V.}

Chief of Training Section of the Educational and Research Centre for Strategic Communications in the sphere of National Security and Defence The National Defence University of Ukraine named after Ivan Cherniakhovskyi

Kyiv, Ukraine

Reforms of military education in line with implementation of NATO educational standards, principles, and best practice are one of the priorities of the Ukrainian armed forces development.

The Presidential Decree of Ukraine «On decision of the National Security and Defence Council of Ukraine dd May 20, 2016 «On 
Strategic Defence Bulletin of Ukraine» defines tasks of military education reform within the whole armed forces reform $[1,3]$.

Thus, there was established Educational and Research Centre for Strategic Communications in the sphere of national security and defence, National Defence University of Ukraine named after Ivan Cherniakhovskyi (hereinafter referred to as the StratCom Centre) in 2018. It is responsible for strategic communications training and advanced training of service members and servants of security and defence institutions, as well as conducts scientific researches in strategic communications.

According to the Annual National Program 2020 approved by the Presidential Decree on May 26, 2020 No. 203/2020 (ANP), Objective 1.3.2 «National System of Strategic Communications», an educational strategic communications model and its realization plan should be developed; Objective 2.2.5 «Defence Forces realize strategic communications in line with European and Euro-Atlantic principles and approaches» - the Ukrainian military should better understand aim and scope of strategic communications due to integration of strategic communications issues in educational system, strategic course integration into curricula of the higher educational establishments at tactical, operational, and strategic levels, development of the StratCom Centre [2].

The StratCom Centre vision is to become a unique interdepartmental institution developing culture of strategic communications and develops the educational interdepartmental system of strategic communications aimed at supporting state strategic communications policy.

The StratCom Centre mission is to contribute to formation of strategic communications culture in security and defence sector, meet needs of security and defence sector in strategic communications specialists, become the communicative platform for effective cooperation among security and defence sector institutions through strategic communications integration into educational process and establish relations with leading Ukraine and NATO educational, scientific organizations.

In 2017 the National Defence University of Ukraine named after Ivan Cherniakhovskyi became the venue for optional strategic 40 
communications course for strategic and operational level students. The course was attended by representatives of George C. Marshall European Centre for Security Studies NATO Defence Education Enhancement Program, NATO Information and Documentation Centre in Ukraine, representatives of Reform Office and Volunteers' Board at the Ministry of Defence of Ukraine. It was conducted according to the ANP 2017, Sub-objective 1.7.3 «Within development of state system of strategic communications to integrate the system of communications professional education and development for defence forces», Objective 1.7 «Development of defence forces capabilities in strategic communications as a part of state and interdepartmental system of strategic communications aimed at supporting formation and realization of policy in security and defence sector of Ukraine, as well as achievement of state defence tasks». This optional course included learning of national, Ministry of Defence of Ukraine, and Armed Forces of Ukraine strategic communications.

In May 2018, in order to develop capabilities of the strategic communications system and development of professional skills of the Ukrainian Ministry of Defence and Armed Forces personnel there was organized the strategic communications course in participation of representatives of the Allied Joint Force Command (JFC) Brunssum. Strategic communications practitioners participated in it.

The ongoing challenges, request of target audiences and necessity to provide strategic communications training at all levels this year the StratCom Centre has conducted for cadets; students of L-2, L-3, and L-4 courses; strategic and operational level students; strategic communications and civil-military cooperation practitioners, etc.

On October 1, 2020, the National Defence University of Ukraine named after Ivan Cherniakhovskyi hosted the First International Scientific Research Conference 'Strategic Communications in Security and Defence: Problems, Experience, and Prospects'. Its coorganizers were National Academy of National Guard of Ukraine, Bohdan Khmelnytskyi National Academy of State Border Service, and National Academy of Security Service of Ukraine. Foreign strategic communications practitioners (representatives of Joint 
Special Operations University, Lithuanian expert) actively participated in the event.

Generally, the representatives of 27 strategic communications institutions and organizations participated in the conference. They shared own experience in development of strategic communications system, integration of strategic communications courses in their curricula, as well as defined educational prospects of strategic communications system.

The Conference importance is proved by the fact that it was conducted during critical times for Ukraine as one of tasks of midterm defence reform is «Strategic Communications» project, as well as the task of development of strategic communications is defined in new National Security Strategy of Ukraine.

According to the conference participants, this joint international event is a key element of development of strategic communications in national defence and security in terms of training of service members and servants considering NATO best practice, as well as necessity to conduct systematically these events. The StratCom Centre is currently ready to cooperate with leading world strategic communications educational and scientific institutions and participate in activities related to development of strategic communications.

\section{References:}

1. Shchypanskyi P. V., Tymoshenko R. I., Salkutsan S. M. Problemy viiskovoi osvity// Nauka i oborona. - 2017. - № 2 S. 37-42. (Shchypanskyi P. V., Tymoshenko R. I., Salkutsan S. M.. Military Education Problems // Nauka i oborona. - 2017. - No. 2 pp. 37-42.)

2. Richna natsionalna prohrama pid ehidoiu Komisii Ukraina NATO na 2020 rik, zatverdzhenoi Ukazom Prezydenta Ukrainy vid 26 travnia 2020 roku № 203/2020. URL: https://www.president.gov.ua/documents/2032020-33861 (data zvernennia: 11.11.2020) (Annual National Program under auspices of Ukraine - NATO Commission 20202 approved by the Presidential Decree of Ukraine dd May 26, 2020 No.203/2020. URL: https://www.president.gov.ua/documents/2032020-33861 (accessed on: 11.11.2020)). 
3. Ukaz Prezydenta Ukrainy № 240/2016 «Pro rishennia Rady natsionalnoi bezpeky i oborony Ukrainy vid 20 travnia 2016 roku «Pro Stratehichnyi oboronnyi biuleten Ukrainy»« vid 6 chervnia 2016 r. URL: http://zakon.rada.gov.ua/laws/show/240/2016 (data zvernennia: 11.11.2020) (Presidential Decree of Ukraine No.240/2016 «On decision of the National Security and Defence Council of Ukraine dd May 20, 2016 «On Strategic Defence Bulletin of Ukraine». URL: http://zakon.rada.gov.ua/laws/show/240/2016 (accessed on: 11.11.2020)).

DOI https://doi.org/10.30525/978-9934-26-005-6-9

\title{
УПРАВЛІНСЬКА КУЛЬТУРА ЯК СОЦІОКУЛЬТУРНИЙ МЕХАНІЗМ ПЕРЕХОДУ ДО ПУБЛІЧНОГО УПРАВЛІННЯ В УКРӒ̈НІ
}

\author{
Пержун В. В. \\ кандидат сочіологічних наук, дочент, \\ докторант \\ Начіональної академії державного управління \\ при Президентові України \\ м. Чернівиі, Україна
}

Соціокультурна сфера відображає й направлена на виявлення різноманітних характеристик життєдіяльності людини i соціально-професійних груп суспільства; навіть більше, координує, направляє і певним чином обмежує людей у поглядах i практичних кроках перетворення суспільних відносин. У нашому випадку це стосується управлінської культури як соціокультурного механізму, що сприяє переходу до результативного публічного управління.

У публічному управлінні має, на нашу думку, формуватися управлінська культура, що базується на спільних інтересах, ідеалах, цінностях і певній управлінській поведінці. Але така 